\title{
Cisplatin plus vinorelbine as induction treatment in stage IIIA non-small cell lung cancer
}

\author{
MAGDA PALKA ${ }^{1}$, ANTONIO SANCHEZ ${ }^{1}$, MAR CÓRDOBA ${ }^{2}$, GEMA DÍAZ NUEVO ${ }^{3}$, \\ ANDRÉS VARELA DE UGARTE ${ }^{2}$, BLANCA CANTOS ${ }^{1}$, MIRIAM MÉNDEZ ${ }^{1}$, \\ VIRGINIA CALVO $^{1}$, CONSTANZA MAXIMIANO $^{1}$ and MARIANO PROVENCIO ${ }^{1}$ \\ Departments of ${ }^{1}$ Clinical Oncology, ${ }^{2}$ Thoracic Surgery and ${ }^{3}$ Pneumology, Puerta de Hierro Hospital, 28222 Madrid, Spain
}

Received December 4, 2014; Accepted January 11, 2016

DOI: $10.3892 / 01.2017 .5620$

\begin{abstract}
Survival rates in patients with stage IIIA non-small cell lung cancer (NSCLC) remain low despite curative treatment. This is due to tumor recurrence at distant sites. The aim of neoadjuvant chemotherapy (NA-CT) is to eradicate occult micrometastatic disease and improve survival in patients that are not candidates for surgery following induction therapy. A total of 21 patients with ipsilateral mediastinal node involvement (N2) with potentially resectable disease, who had been diagnosed with stage IIIA (T1-3 N1-2 and T4N0) NSCLC and who had received cisplatin and vinorelbine as induction treatment were included in this retrospective study. Patients who responded to the treatment underwent surgery, and those who were unresponsive received radical radiotherapy. Follow-up was conducted between March 2008 and April 2014. The median age of patients was 61 years, and all patients exhibited a good Eastern Cooperative Oncology Group performance status. The majority of patients were histologically diagnosed with adenocarcinoma $(48 \%)$ or squamous cell carcinoma (38\%), which was a poor prognostic factor for overall survival (OS). A total of 7 patients underwent surgery (of which 6 were down-staged), with a 3-year survival rate of $42.8 \%$. The most significant factor associated with response to induction treatment was multistation nodal involvement. The complete resection rate for surgical patients was $85.7 \%$. Unresectable patients had a 3-year survival rate of $25.8 \%$. OS time for the whole cohort was 28.5 months, and the 3-and 5-year OS rates were $28.5 \%$ and $4.7 \%$, respectively. CT-induced toxicity did not affect any treatment regime or surgical procedures. In conclusion, the use of cisplatin plus vinorelbine is feasible in a neoadjuvant setting, with good response rates and acceptable
\end{abstract}

Correspondence to: Dr Magda Palka or Dr Mariano Provencio, Department of Clinical Oncology, Puerta de Hierro Hospital, 1 Calle Manuel de Falla, Majadahonda, 28222 Madrid, Spain

E-mail: magda_palka@hotmail.com

E-mail: mprovenciop@gmail.com

Key words: neoadjuvant chemotherapy, stage III non-small cell lung cancer, induction treatment, survival, cisplatin, vinorelbine toxicity. Multistation N2 involvement is the main prognostic factor for a poor response to induction treatment.

\section{Introduction}

Non-small cell lung cancer (NSCLC) accounts for $~ 80 \%$ of all lung cancers. Surgery remains the main treatment for early-stage NSCLC patients (1). Operable patients with stage IA-IIIA disease (2) are candidates for resection surgery with curative intent; this group accounts for $\sim 35 \%$ of all lung cancer cases. However, in a large number of patients, tumors recur following surgical resection (3). Five-year survival rates are variable, at $57-67 \%$ and $39-55 \%$ for stage I and II disease, respectively (3). Patients with completely resected stage IIIA disease exhibit a 5-year overall survival (OS) rate of $\sim 25 \%$. The most frequent cause of mortality in these patients is distant metastases $(4,5)$. Occult micrometastatic disease, which remains undetected at the time of presurgical staging, may be the cause of recurrence in distant sites following surgery. Therefore, eradicating early metastatic disease using chemotherapy (CT) may reduce the incidence of recurrence at distant sites, subsequently improving survival (6). CT may be administrated prior to [induction or neoadjuvant CT (NA-CT)] or subsequent to (adjuvant CT) surgery.

At present, NA-CT is the standard treatment for stage IIIA NSCLC. It is known to improve survival in patients who are not candidates for surgery following induction CT; however, response and survival rates remain low (7).

Theoretical advantages of induction CT include in vivo evaluation of response to $\mathrm{CT}$, which may identify patients that would benefit from adjuvant treatment; early micrometastatic treatment, which may prevent disease recurrence at distant sites; reduced drug resistance due to early CT exposure; and increased resectability and conservation of healthy pulmonary parenchyma (6).

However, identification of patients that may benefit from surgery following induction CT is controversial. A previous by the Southwestern Oncology Group (8) indicated that surgery should be avoided in cases where mediastinal involvement persists subsequent to NA-CT. In this previous study, patients with complete pathological response exhibited a median survival time of 30 months compared to 10 months in patients with residual tumor. 
Novel chemotherapeutic drugs that have demonstrated efficacy in the treatment of metastatic disease, including gemcitabine (9), paclitaxel (10), vinorelbine (9) and docetaxel (11), have been added to neoadjuvant treatment regimens, with response rates of $44-80 \%$, and complete resection rates of $67-79 \%$. The aforementioned drugs are also strong radiosensitizing agents.

In the current study, the effect of NA-CT treatment with cisplatin plus vinorelbine on OS was analyzed in $21 \mathrm{~N} 2$ patients diagnosed with potentially resectable NSCLC.

\section{Patients and methods}

Patient cohort. A total of 21 patients were included and retrospectively analyzed, meeting the following inclusion criteria: Adults over 18 years, histologically diagnosed with stage IIIA (T1-3 N1-2 and T4N0) NSCLC between March 2008 and December 2011. Patients required available tissue remaining from biopsy for analysis, had to have been treated with cisplatin and vinorelbine NA-CT and were followed up at the Puerta de Hierro Hospital (Madrid, Spain). All patients were followed up until April 2014. The study adhered to the principles of the Declaration of Helsinki and Good Clinical Practice guidelines (12), and was approved by the institutional review board of Puerta de Hierro Hospital.

The clinical records of the patient cohort were reviewed; this included the patient medical history and results of physical examination, basic biochemical blood tests, blood count, blood clotting tests, chest X-rays and biopsies, with a diagnosis of NSCLC in all cases.

Patients underwent initial positron emission tomography (PET)/computed tomography, as well as pathological assessment of mediastinal nodes by biopsy or cytology. Staging was determined according to the 7th edition of TNM Classification of Malignant Tumours (13).

All cases were submitted to the thoracic tumor committee, which includes radiation oncologists, pulmonologists, thoracic surgeons, radiologists, nuclear medicine physicians, pathologists and medical oncologists, where the neoadjuvant treatment approach was selected.

All patients received three 21-day cycles of induction treatment with $75 \mathrm{mg} / \mathrm{m}^{2}$ intravenous cisplatin (day 1) and $25 \mathrm{mg} / \mathrm{m}^{2}$ vinorelbine (days 1 and 8 ).

Treatment response was assessed by PET/computed tomography; if a response was observed, mediastinal node involvement was re-evaluated. Cases that had been down-staged and were suitable for surgery subsequently underwent lobectomy or bilobectomy.

The following patient characteristics were evaluated: Gender, smoking history, age at diagnosis, comorbidities (including hypertension, chronic obstructive pulmonary disease, heart disease, diabetes mellitus, transplant and coagulopathy), personal history of cancer, Eastern Cooperative Oncology Group performance status (ECOG PS) (14), tumor histology, and tumor stage at diagnosis. Data relating to induction treatment response and disease evolution were also recorded.

Progression-free survival (PFS) was defined as the time between diagnosis date and the date when the first recurrence or progression was identified, and OS time was defined as the period between diagnosis of lung cancer and patient mortality.
Statistical analysis. Qualitative variables were expressed as absolute frequency and percentage. Normal distributions were tested using the Shapiro-Wilk test. Mean comparisons between groups of continuous variables with normal distribution were compared using the Student's $t$-test for unpaired samples, while those with an asymmetric distribution were compared using the Mann-Whitney U test. The $\chi^{2}$ test and Fisher's exact test were used to analyze qualitative variables. A hazard ratio (HR) and $95 \%$ confidence interval $(95 \% \mathrm{CI})$ were estimated for each variable. $\mathrm{P}$-values were two-sided, and $\mathrm{P}<0.05$ was considered to indicate a statistically significant difference. SPSS 14.0 software (SPSS, Inc., Chicago, IL, USA) was used for all statistical analyses.

\section{Results}

Patient characteristics. The general characteristics of the patients at diagnosis and patient response to NA-CT are shown in Table I. All patients exhibited an ECOG PS of 0 or 1, the mean age of patients was 62.57 years (range, 45-73 years) and $62 \%$ of patients exhibited $>2$ relevant comorbidities. All patients exhibited stage IIIA NSCLC at diagnosis, and 14 patients exhibited N2, multistation, or bulky mediastinal node involvement. Bulky disease was defined as mediastinal lymph nodes measuring $>2 \mathrm{~cm}$ at the longest axis. No cases of CT-induced toxicity resulting in treatment delay occurred.

Patient response to NA-CT. A total of 10 patients (48\%) exhibited response to induction treatment; a total of 4 patients $(19 \%)$ exhibited a complete response and 6 patients (29\%) exhibited a partial response according to the Response Evaluation Criteria In Solid Tumors criteria (15). However, pathological down-staging was only verified in 7 cases (33\%). A total of 9 patients exhibited a stable response, and 2 progressed following NA-CT. The characteristics of the patients that were successfully down-staged following induction treatment are shown in Table II.

Univariate analysis revealed a significant association between multistation or bulky nodal involvement and response to induction $\mathrm{CT}$. This association indicated that the response to NA-CT was worse in patients who exhibited this type of nodal involvement, with an odds ratio of 15 (95\% CI, 1.34-167.63; $\mathrm{P}=0.0446$ ) (Table III). However, no significant difference was identified between response to NA-CT and other clinicopathological factors, such as gender, smoking history, ECOG PS, histology, primary lesion size and nodal involvement.

Treatment following induction CT. A total of 7 (33\%) patients underwent surgery (lobectomy): 3 of the 4 patients who had exhibited a complete response, and 4 out of 6 who had exhibited a partial response. Of the 7 patients that underwent surgery, 6 underwent complete resection (defined as tumor-free surgical margins and superior mediastinal nodes in the surgical specimen with no infiltration of tumor cells). The surgery-associated mortality rate was $0 \%$, as no patient mortalities occurred within the first 30 days following surgery. Patients who had shown no response to NA-CT were treated with radical radiotherapy at doses of $\leq 66$ Gy (dose range from 45-66 Gy administered in a daily schedule at a fraction of $1.8 \mathrm{cGy}$ per day).

Follow-up. The median OS time in the cohort was 28.5 months (range, 9-62 months), and the 3- and 5-year OS rates were 
Table I. Clinicopathological characteristics of 21 stage IIIA non-small cell lung cancer patients.

\begin{tabular}{|c|c|}
\hline Parameter & Patients \\
\hline Median age at diagnosis, years & 62.57 \\
\hline \multicolumn{2}{|l|}{ Gender, n (\%) } \\
\hline Female & $4(19)$ \\
\hline Male & $17(81)$ \\
\hline \multicolumn{2}{|l|}{ Age, years } \\
\hline Mean & 62.57 \\
\hline Range & $45-73$ \\
\hline \multicolumn{2}{|l|}{ Smoking history, n (\%) } \\
\hline Non-smokers & $3(15)$ \\
\hline Smokers & $18(85)$ \\
\hline \multicolumn{2}{|l|}{ ECOG PS, n (\%) } \\
\hline 0 & $16(76)$ \\
\hline 1 & $5(24)$ \\
\hline \multicolumn{2}{|l|}{ Comorbidities, n (\%) } \\
\hline $0-1$ & $8(38)$ \\
\hline $2-3$ & $9(43)$ \\
\hline$>3$ & $4(19)$ \\
\hline \multicolumn{2}{|l|}{ Histology, n (\%) } \\
\hline Adenocarcinoma & $10(48)$ \\
\hline Squamous cell carcinoma & $8(38)$ \\
\hline Large cell carcinoma & $3(14)$ \\
\hline \multicolumn{2}{|l|}{ TNM stage, n (\%) } \\
\hline T1-3, N0-1 & $1(5)$ \\
\hline $\mathrm{T} 1-3, \mathrm{~N} 2$ & $17(81)$ \\
\hline T4N0 & $3(14)$ \\
\hline \multicolumn{2}{|l|}{$\begin{array}{l}\text { Bulky or multistation } \\
\text { node involvement, } \mathrm{n}(\%)\end{array}$} \\
\hline Yes & $14(67)$ \\
\hline No & $7(33)$ \\
\hline \multicolumn{2}{|l|}{ Response to NA-CT, n (\%) } \\
\hline Complete & $4(19)$ \\
\hline Partial & $6(29)$ \\
\hline Stable & $9(43)$ \\
\hline Progression & $2(9)$ \\
\hline \multicolumn{2}{|l|}{ Down-staged, n (\%) } \\
\hline Yes & $7(33)$ \\
\hline No & $14(67)$ \\
\hline \multicolumn{2}{|l|}{ Surgical treatment, n (\%) } \\
\hline Yes & $7(33)$ \\
\hline No & $14(67)$ \\
\hline
\end{tabular}

ECOG PS, Eastern Cooperative Oncology Group performance status; NA-CT, neoadjuvant chemotherapy. T, tumor; N, node; M, metastasis.

28.5 and $4.7 \%$, respectively. By the end of follow up in April $2014,13 / 21$ patients included in the study had died, $92.3 \%$ of whom had succumbed due to tumor progression. Figs. 1 and 2 show the PFS and OS of the patient cohort, respectively. The

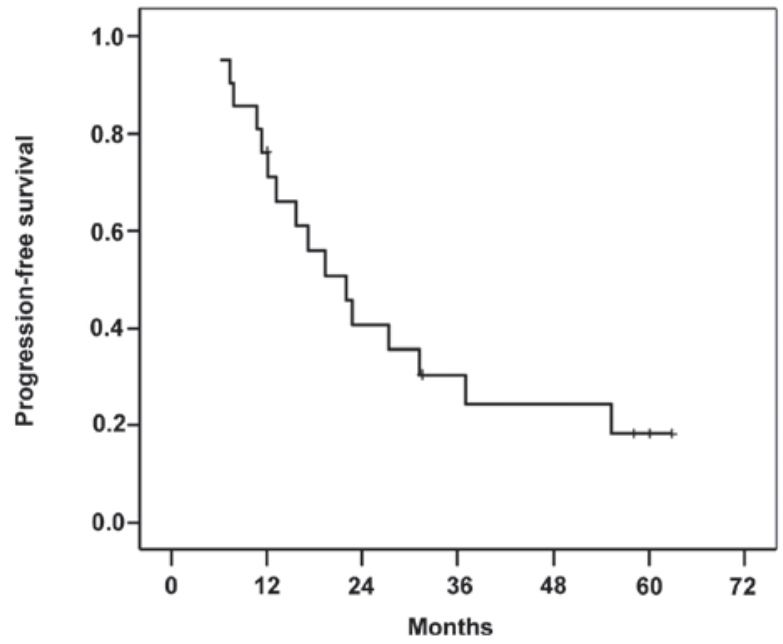

Figure 1. Progression-free survival. A Kaplan-Meier graph for progression-free survival of the entire patient cohort. The 3-year disease free survival was $23.8 \%$, which entailed a median of 19.4 months progression-free survival.

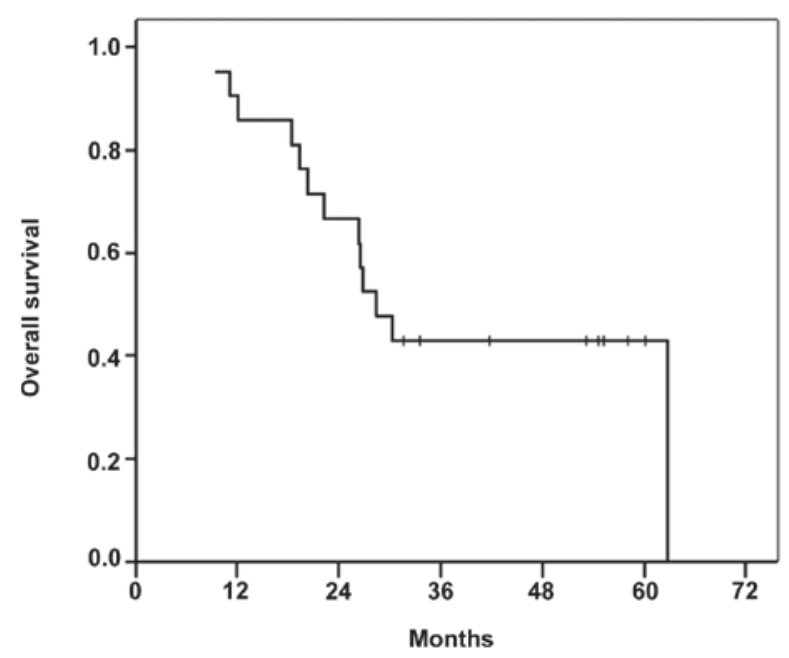

Figure 2. Overall survival. The Kaplan-Meier graph shows overall survival of the entire patient cohort. The 3 -year overall survival rate was $28.5 \%$, which implies a median overall survival of 28.5 months.

3-year survival rate of the patients that underwent surgery was $42.8 \%$, compared to $28.5 \%$ in non-surgical patients. For the patients who remained alive upon completion of the study, the follow-up period was 40 months.

Overall, the whole cohort exhibited a 3-year disease-free survival rate of $23.8 \%$, and a 5 -year disease-free survival rate of $4.7 \%$. The median PFS time was 19.4 months (range, 6-62 months), and $76 \%$ of patients exhibited tumor recurrence.

In the group of patients who were successfully down-staged, 4/7 (57.1\%) patients exhibited recurrence, with a PFS time of 18 months (range, 3-58 months). Among the non-down-staged patients, $12(85 \%)$ exhibited recurrence, with a PFS time of 14 months (range, 6-55 months).

Patients who underwent surgery exhibited a median PFS time of 10 months (range, 3-18 months) and 5 (71\%) patients exhibited recurrence. No significant differences between any of the clinicopathological patient characteristics analyzed and PFS were identified. 
Table II. Comparison of patient characteristics of down-staged $(n=7)$ and non-down-staged patients $(n=14)$.

A, Clinicopathological parameters of patients.

\begin{tabular}{|c|c|c|}
\hline Parameter & Down-staged patients & Non-down-staged patients \\
\hline Median age (range), years & $62(50-70)$ & $61(45-73)$ \\
\hline \multicolumn{3}{|l|}{ Gender, $\mathrm{n}$} \\
\hline Female & 1 & 3 \\
\hline Male & 6 & 11 \\
\hline \multicolumn{3}{|l|}{ ECOG PS, n } \\
\hline 0 & 6 & 10 \\
\hline 1 & 1 & 4 \\
\hline \multicolumn{3}{|l|}{ Smoking history, $\mathrm{n}$} \\
\hline Smoker & 6 & 11 \\
\hline Non-Smoker & 0 & 3 \\
\hline Unknown & 1 & 0 \\
\hline \multicolumn{3}{|l|}{ Histology, n } \\
\hline Adenocarcinoma & 4 & 6 \\
\hline Squamous cell carcinoma & 1 & 7 \\
\hline Large cell carcinoma & 2 & 1 \\
\hline \multicolumn{3}{|c|}{$\begin{array}{l}\text { Multistation/bulky mediastinal } \\
\text { node involvement, } \mathrm{n}\end{array}$} \\
\hline Yes & 4 & 10 \\
\hline No & 3 & 4 \\
\hline
\end{tabular}

B, TNM stages of patients pre- and post-chemotherapy

\begin{tabular}{|c|c|c|}
\hline \multirow[b]{2}{*}{ Patients } & \multicolumn{2}{|c|}{ TNM stage } \\
\hline & preNA-CT & postNA-CT \\
\hline \multirow[t]{7}{*}{ Down-staged patients } & T1N2 & TONO \\
\hline & $\mathrm{T} 2 \mathrm{~N} 2$ & TONO \\
\hline & $\mathrm{T} 2 \mathrm{~N} 2$ & TONO \\
\hline & $\mathrm{T} 3 \mathrm{~N} 2$ & TONO \\
\hline & $\mathrm{T} 3 \mathrm{~N} 2$ & yT3N0 \\
\hline & $\mathrm{T} 1 \mathrm{~N} 2$ & yT2N0 \\
\hline & T3N1 & yT2N0 \\
\hline \multirow[t]{14}{*}{ Non-down-staged patients } & $\mathrm{T} 2 \mathrm{~N} 2$ & $\mathrm{~T} 2 \mathrm{~N} 2$ \\
\hline & T3N2 & $\mathrm{T} 3 \mathrm{~N} 2$ \\
\hline & $\mathrm{T} 2 \mathrm{~N} 2$ & $\mathrm{~T} 2 \mathrm{~N} 2$ \\
\hline & T4N0 & T4N0 \\
\hline & T3N2 & T3N2 \\
\hline & $\mathrm{T} 2 \mathrm{~N} 2$ & $\mathrm{~T} 2 \mathrm{~N} 2$ \\
\hline & $\mathrm{T} 3 \mathrm{~N} 2$ & $\mathrm{~T} 3 \mathrm{~N} 2$ \\
\hline & $\mathrm{T} 2 \mathrm{~N} 2$ & $\mathrm{~T} 2 \mathrm{~N} 2$ \\
\hline & T4N0 & T4N0 \\
\hline & $\mathrm{T} 2 \mathrm{~N} 2$ & $\mathrm{~T} 2 \mathrm{~N} 2$ \\
\hline & $\mathrm{T} 2 \mathrm{~N} 2$ & $\mathrm{~T} 2 \mathrm{~N} 2$ \\
\hline & T4N0 & T4N0 \\
\hline & $\mathrm{T} 2 \mathrm{~N} 2$ & T2N2M1 \\
\hline & $\mathrm{T} 3 \mathrm{~N} 2$ & $\mathrm{~T} 3 \mathrm{~N} 2$ \\
\hline
\end{tabular}


Table III. Response to chemotherapy and presence of multistation or bulky lymph node involvement in non-small cell lung cancer patients.

\begin{tabular}{lcc}
\hline $\begin{array}{l}\text { Response to } \\
\text { neoadjuvant chemotherapy }\end{array}$ & $\begin{array}{c}\text { Patients, } \\
\mathrm{n}\left(\%^{\mathrm{a}}\right)\end{array}$ & $\begin{array}{c}\text { Patients with multistation/bulky } \\
\text { involvement, } \mathrm{n}\left(\%^{\mathrm{b}}\right)\end{array}$ \\
\hline Complete & $4(19)$ & $1(25)$ \\
Partial & $6(29)$ & $3(50)$ \\
Stable & $9(43)$ & $8(89)$ \\
Progression & $2(9)$ & $2(100)$ \\
\hline
\end{tabular}

a\% of total; b\% of subgroup. Odds ratio, $15 ; 95 \%$ confidence interval, 1.3-167.6; $\mathrm{P}=0.0446$.

Of the down-staged patient group, $4(57 \%)$ patients died, with an OS time of 58 months (range, 19-62 months). In the non-down-staged group, 9/14 patients died (64.2\%) with a median OS time of 27 months (range, 8-58 months).

A significant association between tumor histology and OS was identified; squamous cell carcinoma, which was diagnosed in 8 patients (of whom 7 had died by the end of the study), was associated with a shorter OS time $(\mathrm{P}=0.029)$.

No statistically significant differences were identified between OS and gender, smoking history, ECOG PS, tumor size, nodal involvement, multistation or bulky disease, down-staging or surgery.

A total of $12(57 \%)$ patients exhibited distant metastasis at the end of the study. Distant metastasis to the lung ( 7 cases) and central nervous system (5 cases) occurred most frequently, whereas bone and mediastinal metastasis were less common.

\section{Discussion}

Patients with stage IIIA N2 NSCLC exhibit 5-year OS rates of $10-15 \%$. In stage IIIA N2 patients with multistation or bulky disease this rate is only $2-5 \%$. The efficacy of surgical treatment in these cases is controversial. In four previous studies, which included a total of 1,180 patients undergoing surgery, the 5 -year OS rates ranged from 14 to $30 \%$ (16-19). However, these studies used different inclusion criteria, included patients with different prognoses, defined 'resectable disease' or 'marginally resectable tumor' differently, and used varying CT regimens as induction or adjuvant treatment. Therefore, comparisons must be considered with caution. Despite these limitations, other studies suggest that treatment with cisplatin-based CT improves survival in NSCLC patients (7,20-25).

Generally, patients treated with NA-CT exhibit a median survival time of 20 months and a 3 -year survival rate of $34 \%(6,26)$. This is consistent with the results of the present study, in which OS was 28 months and PFS was 19.5 months.

Complete resection, down-staging and complete resection are predictors of long-term survival $(27,28)$. There is a variability in recurrence free survival following radical treatment of stage III non-small cell lung cancer, and the above-mentioned factors may assist with the selection of patients who will show greater benefit from thoracic surgery. Patients who undergo tumor resection have longer survival times than those who do not $(29,30)$.
Complete pathological response following NA-CT typically varies from 0 to $9.5 \%(20,24,28)$. Two previous studies reported rates of $16.7 \%$ (31) and $15 \%$ (32); however, this is rare. In the present study, the complete response rate was $19 \%$. This was a notable results, although it did not correlate significantly with survival due to the small sample size. The type of response to neoadjuvant chemotherapy (complete, partial, stable or progressive disease) correlated with the presence $r$ not of bulky or multistation mediastinal nodal involvement. In addition, the current study found a median OS time of 58 months in patients achieving pathological tumor response, which was significantly higher than that of patients with no response, who exhibited an OS time of 27 months.

Andre et al (33) analyzed a cohort of 702 patients with N2 NSCLC and identified four negative risk factors: clinical evidence of $\mathrm{N} 2$ prior to surgery, multistation mediastinal lymph node involvement, and pT3 or pT4 stage disease. Choi et al (34), found that, among the 19 clinical pathological prognostic factors studied in patients with pathological evidence of N2 NSCLC, incomplete resection and persistent $\mathrm{N} 2$ disease after induction $\mathrm{CT}$ were negative prognostic factors in univariate analysis. Clinical evidence of N2 disease, multistation mediastinal lymph node involvement and adenocarcinoma histology indicated a poorer prognosis; however, no statistical significance was identified. Furthermore, adjuvant CT administration did not significantly improve prognosis.

Univariate analysis indicated that complete resection and adjuvant $\mathrm{CT}$ were favorable prognostic factors in the present study in 6/7 patients who underwent surgery and complete resection. Complete resection is an established prognostic factor in several previous studies $(27,28,34,35)$. In these previous studies, overall survival and progression free survival were increased in those patients who achieved complete resection. Adjuvant chemotherapy demonstrated an improvement in survival when compared with patients treated with surgery or radiotherapy only $(4,20)$.

In the present study, squamous cell carcinoma was significantly associated with a shorter OS time and thus is considered a negative prognostic factor. Clinicopathological variables, including gender, smoking history, ECOG, primary tumor size, nodal involvement, multistation lymph nodes and bulky disease, were not statistically associated with OS.

Clinical trials specifically designed for patients with stage IIIA NSCLC are listed in Table IV; five of the studies included did not reach recruitment targets, mainly due to 


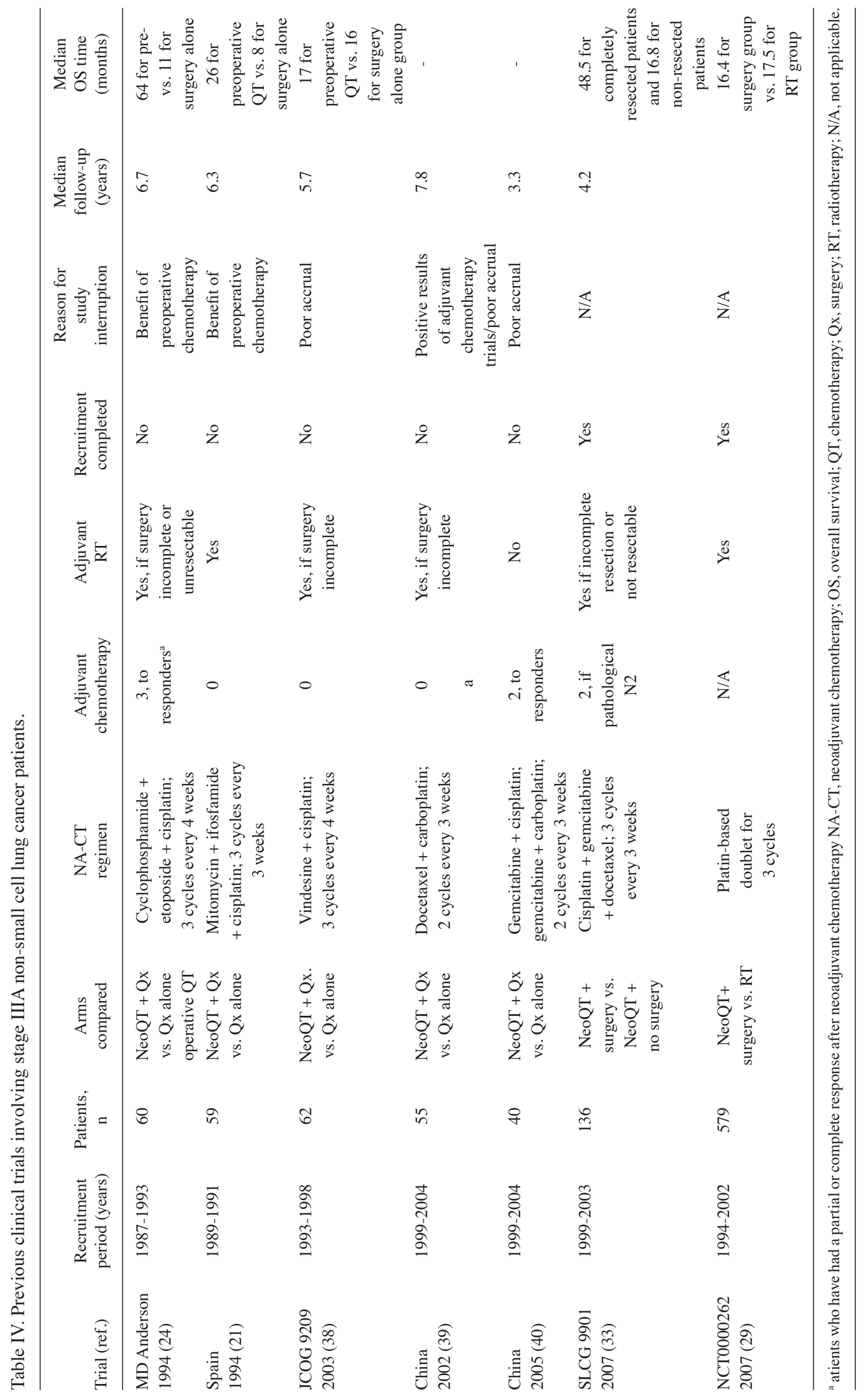


differences identified in the treatment arms. Only the Spanish Lung Cancer Group 9901 and the NCT0000262 trials were completed.

The Spanish Lung Cancer Group (36) study included 136 patients with locally advanced NSCLC. Due to the homogeneity of patients enrolled and the geographical location, this is a good reference trial, despite the clear differences in scientific evidence obtained from clinical trials and patient series. The overall complete resection rate was $68.9 \%$ among patients eligible for surgery (72\% of stage IIIA patients and $66 \%$ of stage IIIB patients) and $48 \%$ of all assessable patients. In the present study, the overall resection rate for all assessable patients was $85.7 \%$. In the aforementioned trial (36), the rate of complete pathological response was $12.9 \%$ of 62 completely resected patients, compared with $42.85 \%$ in the present study (of 7 patients undergoing surgery, 3 showed complete pathological response in the surgical specimen). However, the fact that the results may have been strongly influenced by the sample size must be considered.

With regard to CT and surgery-related toxicities, in the Spanish group trial (36), 6/136 patients withdrew from the study due to CT toxicity, and 7 patients $(7.8 \%)$ died during the postoperative period. The trial used a platin-based regimen with three drugs, which differs from the current standard treatment, a platin-based doublet, as used in the current study. No NA-CT, surgery or radiotherapy treatment was delayed due to secondary effects in the present study cohort, and the surgical death rate was $0 \%$. The safety of this regimen has been evaluated previously in clinical trials; Krzakowski et al (37) investigated the use of this doublet in combination with radiotherapy for the treatment of stage III NSCLC. The median OS time of patients was 15.9 months, and 3-year survival rate was $36.8 \%$ (37). In the present study, OS time was 28.5 months, and the 3 -year survival rate was $28.5 \%$. In the study by Krzakowski et al (37), the median survival time was 48.5 months in 62 completely resected patients, 12.9 months in 13 incompletely resected patients, and 16.8 months in 15 non-resected patients $(\mathrm{P}=0.005)$. In the present study non-resected patients, the OS time was 27 months. However, the higher median OS times observed in the current study may be due to the small sample size.

In the Spanish group trial (36), the 3-year survival rate was $60.1 \%$ in completely resected patients and $31.1 \%$ in non-resected patients. In the present study, it was $42.8 \%$ in surgical patients, and $28.5 \%$ in non-surgical patients. In the Spanish group trial study, clinical response and age ( $<60$ years) were the most significant prognostic factors (HR, 0.35; $\mathrm{P}<0.0001$; and HR,0.64; $\mathrm{P}=0.027$, respectively) (36).

In conclusion, cisplatin plus vinorelbine is a feasible regimen in the neoadjuvant setting with good response rates and acceptable toxicity. The most significant factor associated with a poor response to induction treatment was multistation or bulky N2 mediastinal lymph node involvement. However, further studies are required, as long-term survival rates in stage III NSCLC remain low.

\section{Acknowledgements}

This study was supported by the Instituto de Investigación Carlos III-PI (grant no. 13/01806) (MP).

\section{References}

1. American Cancer Society: Lung cancer (Non-small cell). Atlanta, GA, USA, 2016

2. Mirsadraee S, Oswal D, Alizadeh Y, Caulo A and van Beek E Jr: The 7th lung cancer TNM classification and staging system: Review of the changes and implications. World J Radiol 4: 128-134, 2012.

3. Lim E, Harris G, Patel A, Adachi I, Edmonds L and Song F: Preoperative versus postoperative chemotherapy in patients with resectable non-small cell lung cancer: Systematic review and indirect comparison meta-analysis of randomized trials. J Thorac Oncol 4: 1380-1388, 2009.

4. Arriagada R, Dunant A, Pignon JP, Bergman B, Chabowski M, Grunenwald D, Kozlowski M, Le Péchoux C, Pirker R, Pinel MI, et $a l$ : Long-term results of the international adjuvant lung cancer trial evaluating adjuvant Cisplatin-based chemotherapy in resected lung cancer. J Clin Oncol 28(1): 35-42, 2010.

5. Howlader N, Noone AM, Krapcho M, Miller D, Bishop K, Altekruse SF, Kosary CL, Yu M, Ruhl J, Tatalovich Z, Mariotto A, et al (eds). SEER Cancer Statistics Review, 1975-2013, National Cancer Institute. Bethesda, MD. http://seer.cancer.gov/csr/1975_2013. Accessed September 1, 2016.

6. NSCLC Meta-analysis Collaborative Group: Preoperative chemotherapy for non-small-cell lung cancer: A systematic review and meta-analysis of individual participant data. Lancet 383: 1561-1571, 2014.

7. Depierre A, Milleron B, Moro-Sibilot D, Chevret S, Quoix E, Lebeau B, Braun D, Breton JL, Lemarié E, Gouva S, et al: Preoperative chemotherapy followed by surgery compared with primary surgery in resectable stage I (except T1N0), II and IIIa non-small-cell lung cancer. J Clin Oncol 20: 247-253, 2002.

8. Albain KS, Rusch VW, Crowley JJ, Rice TW, Turrisi AT III, Weick JK, Lonchyna VA, Presant CA, McKenna RJ, Gandara DR, et al: Concurrent cisplatin/etoposide plus chest radiotherapy followed by surgery for stages IIIA (N2) and IIIB non-small-cell lung cancer: Mature results of southwest oncology group phase II study 8805. J Clin Oncol 13: 1880-1892, 1995.

9. Vokes EE, Herndon JE II, Crawford J, Leopold KA, Perry MC, Miller AA and Green MR: Randomized phase II study of cisplatin with gemcitabine or paclitaxel or vinorelbine as induction chemotherapy followed by concomitant chemoradiotherapy for stage IIIB non-small-cell lung cancer: Cancer and leukemia group B study 9431. J Clin Oncol 20: 4191-4198, 2002.

10. O'Brien ME, Splinter T, Smit EF, Biesma B, Krzakowski M, Tjan-Heijnen VC, Van Bochove A, Stigt J, Smid-Geirnaerdt MJ, Debruyne C, et al: Carboplatin and paclitaxol (Taxol) as an induction regimen for patients with biopsy-proven stage IIIA N2 non-small cell lung cancer. An EORTC phase II study (EORTC 08958). Eur J Cancer 39: 1416-1422, 2003.

11. Zarogoulidis K, Kontakiotis T, Hatziapostolou P, Fachantidou E, Delis D, Goutsikas J, Constantinidis TC and Athanasiadis A: A Phase II study of docetaxel and carboplatin in the treatment of non-small cell lung cancer. Lung Cancer 32: 281-287, 2001.

12. World Medical Association. Declaration of Helsinki: WMA Declaration of Helsinki - Ethical Principles for Medical Research Involving Human Subjects. http://www.wma. net/en/30publications/10policies/b3/. Accessed September 1, 2016.

13. Goldstraw P, Crowley J, Chansky K, Giroux DJ, Groome PA, Rami-Porta R, Postmus PE, Rusch V and Sobin L; International Association for the Study of Lung Cancer International Staging Committee; Participating Institutions: The IASLC lung cancer staging project: Proposals for the revision of the TNM stage groupings in the forthcoming (seventh) edition of the TNM classification of malignant tumours. J Thorac Oncol 2: 706-714, 2007.

14. Oken MM, Creech RH, Tormey DC, Horton J, Davis TE, McFadden ET and Carbone PP: Toxicity and response criteria of the Eastern Cooperative Oncology Group. Am J Clin Oncol 5: 649-655, 1982.

15. Eisenhauer EA, Therasse P, Bogaerts J, Schwartz LH, Sargent D, Ford R, Dancey J, Arbuck S, Gwyther S, Mooney M, et al: New response evaluation criteria in solid tumours: Revised RECIST guideline (version 1.1). Eur J cancer 45: 228-247, 2009.

16. Martini N and Flehinger BJ: The role of surgery in N2 lung cancer. Surg Clin North Am 67: 1037-1049, 1987.

17. Watanabe Y, Shimizu J, Oda M, Hayashi Y, Watanabe S, Tatsuzawa Y, Iwa T, Suzuki M and Takashima T: Aggressive surgical intervention in N2 non-small cell cancer of the lung. Ann Thorac Surg 51: 253-261, 1991. 
18. Naruke T, Goya T, Tsuchiya R and Suemasu K: The importance of surgery to non-small cell carcinoma of lung with mediastinal lymph node metastasis. Ann Thorac Surg 46: 603-610, 1988.

19. Mountain CF: Expanded possibilities for surgical treatment of lung cancer. Survival in stage IIIa disease. Chest 97 1045-1051, 1990.

20. Chemotherapy in non-small cell lung cancer: A meta-analysis using updated data on individual patients from 52 randomised clinical trials. Non-small cell lung cancer collaborative group. BMJ 311: 899-909, 1995.

21. Rosell R, Gómez-Codina J, Camps C, Maestre J, Padille J, Cantó A, Mate JL, Li S, Roig J, Olazábal A, et al: A randomized trial comparing preoperative chemotherapy plus surgery with surgery alone in patients with non-small-cell lung cancer. N Engl J Med 330: 153-158, 1994.

22. Rosell R, Gómez-Codina J, Camps C, Javier Sánchez J Maestre J, Padilla J, Cantó A, Abad A and Roig J: Preresectional chemotherapy in stage IIIA non-small-cell lung cancer: A 7-year assessment of a randomized controlled trial. Lung Cancer 26: 7-14, 1999.

23. Roth JA, Atkinson EN, Fossella F, Komaki R, Bernadette Ryan M, Putnam JB Jr, Lee JS, Dhingra H, De Caro L, Chasen M and Hong WK: Long-term follow-up of patients enrolled in a randomized trial comparing perioperative chemotherapy and surgery with surgery alone in resectable stage IIIA non-small-cell lung cancer. Lung Cancer 21: 1-6, 1998.

24. Roth JA, Fossella F, Komaki R, Ryan MB, Putnam JB Jr, Lee JS, Dhingra H, De Caro L, Chasen M, McGavran M, et al: A randomized trial comparing perioperative chemotherapy and surgery with surgery alone in resectable stage IIIA non-small-cell lung cancer. J Natl Cancer Inst 86: 673-680, 1994.

25. Pass HI, Pogrebniak HW, Steinberg SM, Mulshine J and Minna J: Randomized trial of neoadjuvant therapy for lung cancer: Interim analysis. Ann Thorac Surg 53: 992-998, 1992.

26. Martin J, Ginsberg RJ, Venkatraman ES, Bains MS, Downey RJ, Korst RJ, Kris MG and Rusch VW: Long-term results of combined-modality therapy in resectable non-small-cell lung cancer. J Clin Oncol 20: 1989-1995, 2002.

27. Kirn DH, Lynch TJ, Mentzer SJ, Lee TH, Strauss GM, Elias AD, Skarin AT and Sugarbaker DJ: Multimodality therapy of patients with stage IIIA, N2 non-small-cell lung cancer. Impact of preoperative chemotherapy on resectability and downstaging. J Thorac Cardiovasc Surg 106: 696-702, 1993.

28. Sugarbaker DJ, Herndon J, Kohman LJ, Krasna MJ and Green MR: Results of cancer and leukemia group B protocol 8935. A multiinstitutional phase II trimodality trial for stage IIIA (N2) non-small-cell lung cancer. Cancer and leukemia group B thoracic surgery group. J Thorac Cardiovasc Surg 109: 473-483 discussion 483-485, 1995

29. van Meerbeeck JP, Kramer GW, Van Schil PE, Legrand C, Smit EF, Schramel F, Tjan-Heijnen VC, Biesma B, Debruyne C, van Zandwijk N, et al; European Organisation for Research and Treatment of Cancer-Lung Cancer Group: Randomized controlled trial of resection versus radiotherapy after induction chemotherapy in stage IIIA-N2 non-small-cell lung cancer. J Natl Cancer Inst 99:442-450, 2007.
30. Garrido P, González-Larriba JL, Insa A, Provencio M, Torres A, Isla D, Sanchez JM, Cardenal F, Domine M, Barcelo JR, et al: Long-term survival associated with complete resection after induction chemotherapy in stage IIIA (N2) and IIIB (T4N0-1) non small-cell lung cancer patients: The Spanish Lung Cancer Group Trial 9901. J Clin Oncol 25: 4736-4742, 2007.

31. Martini N, Kris MG, Flehinger BJ, Gralla RJ, Bains MS, Burt ME, Heelan R, McCormack PM, Pisters KM, Rigas JR, et al: Preoperative chemotherapy for stage IIIa (N2) lung cancer: The Sloan-Kettering experience with 136 patients. Ann Thorac Surg 55: 1365-1373; discussion, 1373-1374, 1993.

32. Kumar P, Herndon J, Elias AD, Sugarbaker DJ and Green MR: Comparison of pre-operative thoracic radiation therapy (TRT) to pre-operative chemotherapy (CT) in surgically staged IIIA(N2) non-small cell lung cancer (NSCLC): Initial results of cancer and leukemia group B (CALGB) phase III protocol 9134. Int J Radiation Oncol Biol Phys 39: 195, 1997.

33. Andre F, Grunenwald D, Pignon JP, Dujon A, Pujol JL, Brichon PY, Brouchet L, Quoix E, Westeel V and Le Chevalier T: Survival of patients with resected N2 non-small-cell lung cancer: Evidence for a subclassification and implications. J Clin Oncol 18: 2981-2989, 2000

34. Choi YS, Shim YM, Kim J and Kim K: Recurrence-free survival and prognostic factors in resected pN2 non-small cell lung cancer. Eur J Cardiothorac Surg 22: 695-700, 2002.

35. Rami-Porta R, Mateu-Navarro M, Freixinet J, de la Torre M, Torres-García AJ, Pun YW and Armengod AC; Bronchogenic Carcinoma Cooperative Group of the Spanish Society of Pneumology and Thoracic Surgery (GCCB-S): Type of resection and prognosis in lung cancer. Experience of a multicentre study. Eur J Cardiothorac Surg 28: 622-628, 2005.

36. Garrido P, González-Larriba JL, Insa A, Provencio M, Torres A, Isla D, Sanchez JM, Cardenal F, Domine M, Barcelo JR, et al: Long-term survival associated with complete resection after induction chemotherapy in stage IIIA (N2) and IIIB (T4N0-1) non small-cell lung cancer patients: The Spanish lung cancer group trial 9901. J Clin Oncol 25: 4736-4742, 2007.

37. Krzakowski M, Provencio M, Utracka-Hutka B, Villa E, Codes M, Kuten A, Henke M, Lopez M, Bell D, Biti G, et al: Oral vinorelbine and cisplatin as induction chemotherapy and concomitant chemo-radiotherapy in stage III non-small cell lung cancer: Final results of an international phase II trial. J Thorac Oncol 3: 994-1002, 2008.

38. Nagai K, Tsuchiya R, Mori T, Tada H, Ichinose Y, Koike T and Kato H; Lung Cancer Surgical Study Group of the Japan Clinical Oncology Group: A randomized trial comparing induction chemotherapy followed by surgery with surgery alone for patients with stage IIIA N2 non-small cell lung cancer (JCOG 9209). J Thorac Cardiovasc Surg 125: 254-260, 2003.

39. Wu Y-L, Gu L-J, Weng Y-M, Feng W-N and Cheng C: Neo-adjuvant chemotherapy with docetaxel plus carboplatin for non-small cell lung cancer. Ann Oncol 13 (Suppl 5): 140, 2002.

40. Yang X, Wu Y and Gu L: A randomized trial comparing neoadjuvant gemcitabine plus carboplatin or cisplatin followed by surgery with surgery alone in Clinical Stage IIIA non-small-cell lung cancer (NSCLC). Lung Cancer 49: S288, 2005. 